\title{
Pengaruh Supervisi Akademik Kepala Sekolah Terhadap Kinerja Guru SMA Negeri Di Kota Mataram
}

\author{
Yayuk Yayuk ${ }^{1}$, Agus Ramdani ${ }^{2}$, Syafruddin Syafruddin ${ }^{3}$ \\ 1,2,3 Magister Administrasi Pendidikan \\ email: yayukahyar@gmail.com
}

\begin{abstract}
Academic supervision is all efforts made on an ongoing basis to assist teachers and school principals in developing teacher abilities and performance in managing learning. This study aims to determine the effect of principal academic supervision on teacher performance. The research was conducted in all public high schools in the city of Mataram. This research uses a quantitative approach with an ex post facto design. The study population was all permanent teachers in SMA Negeri in Mataram City. The research sample was taken using proportionate random sampling technique. Data collection techniques with questionnaires and simple linear correlation to test the hypothesis of the strength of the relationship between two independent variables together with one dependent variable. The results showed that the principal's academic supervision had an effect on teacher performance $(P<0.03)$. The success of academic supervision carried out by the principal has an important effect on the performance of teachers in SMA Negeri in Mataram City.
\end{abstract}

Keywords: Academic Supervision, School Principals, Teacher Performance, Ex Post Facto, SMAN In Mataram City.

Abstrak: Supervisi akademik merupakan segala upaya yang dilakukan secara bekesinambungan untuk membantu guru dan kepala sekolah dalam mengembangkan kemampuan dan kinerja guru dalam mengelola pembelajaran. Penelitian ini bertujuan untuk mengetahui pengaruh supervisi akademik kepala sekolah terhadap kinerja guru. Penelitian dilakukan di semua SMA Negeri di Kota Mataram. Penelitian menggunakan pendekatan kuantitatif dengan desain ex post facto. Populasi penelitian adalah seluruh guru tetap yang ada di SMA Negeri di Kota Mataram. Sampel penelitian diambil menggunakan teknik proportionate random sampling. Teknik pengumpulan data dengan angket dan korelasi linear sederhana untuk menguji hipotesis kuatnya hubungan antar dua variabel bebas secara bersama-sama dengan satu variabel terikat. Hasil penelitian menunjukkan bahwa supervisi akademik kepala sekolah berpengaruh terhadap kinerja guru $(\mathrm{P}<0.03)$. Keberhasilan supervisi akademik yang dilakukan oleh kepala sekolah berpengaruh penting terhadap kinerja guru yang ada di SMA Negeri di Kota Mataram.

Kata Kunci: Supervisi akademik, kepala sekolah, Kinerja Guru, ex post facto, SMAN di Kota Mataram.

\section{PENDAHULUAN}

Guru merupakan sumber daya manusia yang berperan signifikan sebagai penggerak dalam suatu sekolah (Murtiningsih, et al., 2019). Tercapai atau tidaknya visi, misi dan tujuan sekolah tergantung kepada personil yang ada di sekolah tersebut, baik secara individu maupun secara tim (Muhammad, 2016). Untuk mencapai tujuan sekolah dapat dilihat dari kinerja guru, karena guru memegang peran penting dalam kegiatan belajar mengajar, dimana guru harus berinteraksi langsung dengan para peserta didik (Hasanah \& Kristiawan, 2019). Karena guru mempunyai peranan penting dalam dunia pendidikan, maka guru harus memiliki kinerja yang baik (Resawati \& Larashati, 2017).

Kinerja guru merupakan faktor penting dalam usaha untuk memberikan pelayanan terbaik dan menciptakan out put/lulusan yang memiliki inteligensi tinggi, berakhlak mulia 
serta mampu berdayaguna di dalam kehidupan masyarakat (Sopandi, 2019). Oleh sebab itu, segala hal yang mempengaruhi kinerja guru harus diperhatikan secara serius. Kinerja guru berkaitan dengan kualitas perilaku yang berorientasi pada tugas dan pekerjaan. Hal ini dapat terlihat dari rasa tanggung jawab moral yang diterima. Semua itu akan terlihat dari kepatuhan dan loyalitas dalam menjalankan tugas keguruan di dalam maupun di luar kelas. Secara umum, kinerja guru dapat diartikan sebagai unjuk kerja/hasil kerja yang dapat dilihat secara kualitas dan kuantitas, dicapai oleh seorang guru dalam melaksanakan tugas dan tanggung jawab yang diberikan kepadanya (Khasanah, \& Kristiawan, 2019). Namun pada kenyataannya di lapangan, masih ada guru yang kurang profesional dalam melaksanakan tugas keprofesiannya, hal ini bisa disebabkan oleh beberapa faktor, salah satu diantaranya dikarenakan guru kurang mampu melaksanakan pembelajaran secara efektif dan efisien sehingga berdampak pada kurang maksimalnya proses pembelajaran yang berlangsung di sekolah.

Rendahnya profesionalitas guru di Indonesia dapat dilihat dari kelayakan guru mengajar. Bukti rendahnya profesionalitas guru dapat terlihat dari masih banyaknya guru yang tidak menguasai berbagai kompetensi (Mujahidin, 2017). Misalnya saja masih banyak guru mengalami kendala dalam menerapkan berbagai strategi pembelajaran. Dalam pembelajaran, seorang guru dituntut untuk mampu mengembangkan berbagai kompetensi yang ada pada dirinya (Ramdani, 2020). Sehingga diharapkan dengan peningkatan kompetensi tersebut akan menciptakan suasana belajar yang lebih menarik. Jika dalam mengajar ternyata guru belum mampu menggunakan variasi metode pembelajaran, maka dikhawatirkan minat siswa dalam belajar akan berkurang (Ghafar, et al., 2019). Jadi untuk meningkatkan kembali minat siswa dalam belajar peran guru sangatlah penting. Guru harus bisa menerapkan beberapa metode pembelajaran yang menarik siswa. Metode pembelajaran harus bervariasi supaya siswa tidak jenuh dan dapat menikmati pembelajaran (Yustiqvar, et al., 2019).

Untuk meningkatkan kinerja guru perlu dilakukan supervisi oleh kepala sekolah sehingga akan membantu guru dalam melaksanakan tugas dan fungsinya di sekolah, salah satunya yaitu supervisi akademik. Kepala sekolah masih minim melakukan pemantauan atas kinerja guru dalam melaksanakan tugas pembelajarannya. Pembelajaran di kelas seolah menjadi masalah intern para guru, termasuk upaya dalam mencari solusi guna meningkatkan hasil belajar dari peserta didiknya (Fathurrahman, 2018). Kepala sekolah dapat dinyatakan sebagai personel yang mempunyai pengetahuan dan pengalaman mengelola pembelajaran yang tertinggi dalam satuan pendidikan, sehingga menjadi sumber yang paling dekat dalam mencari solusi oleh para guru (Suchyadi, 2018).

Kepala sekolah memiliki peranan yang strategis untuk meningkatkan mutu pendidikan suatu sekolah (Kartini, et al., 2020). Kepala sekolah tidak saja berperan sebagai pemimpin pembelajaran, tetapi lebih dari itu kepala sekolah merupakan pemimpin dari semua fungsi-fungsi kepemimpinan dalam suatu sekolah seperti perencanaan, pembinaan karir, koordinasi dan evaluasi (Saani, 2013).

Supervisi akademik yang dilakukan lebih fokus membantu kecakapan guru dalam proses pembelajaran di sekolah. Esensi supervisi akademik sama sekali bukan menilai unjuk kerja guru dalam mengelola proses pembelajaran semata, melainkan membantu guru dalam mengembangkan kemampuan profesionalismenya (Andriani, et al., 2018).

Supervisi akademik adalah bantuan profesional kepada guru, melalui siklus perencanaan yang sistematis, pengamatan yang cermat, dan umpan balik yang objektif dan segera (Khasanah, \& Kristiawan, 2019). Dengan cara itu guru dapat menggunakan balikan tersebut untuk memperhatikan kinerjanya.

Supervisi akademik yang dilakukan oleh kepala sekolah akan mengena pada sasarannya jika dilaksanakan sesuai prosedur, 
artinya ada perencanaan, pelaksanaanya menimbang kaidah-kaidah yang ada, dievaluasi, dan yang tidak kalah pentingnya adalah adanya tindak lanjut dari hasil supervisi tersebut (Renata, et al., 2018).

Penelitian ini bertujuan untuk mengetahui pengaruh supervisi akademik terhadap kinerja guru SMA Negeri di Kota Mataram.

\section{METODE PENELITIAN}

Penelitian ini menggunakan pendekatan kuantitatif (Arikunto, 2013). Penelitian ini merupakan penelitian ex-post facto dengan mengumpulkan data berupa angka-angka dan diolah menggunakan statistik program SPSS versi 16. Penelitian ex-post facto dalam penelitian ini karena ingin menemukan penyebab yang memungkinkan perubahan perilaku, gejala atau fenomena yang disebabkan oleh suatu peristiwa, perilaku atau hal-hal sebagai penyebab perubahan pada variabel bebas yang secara keseluruhan sudah terjadi.

Populasi dalam penelitian ini adalah seluruh guru tetap dari 11 Sekolah Menegah Atas Negeri (SMAN) yang berada di Kota Mataram terdiri dari SMAN 1, SMAN 2, SMAN 3, SMAN 4, SMAN 5, SMAN 6, SMAN 7, SMAN 8, SMAN 9, SMAN 10, dan SMAN 11 Mataram. Jumlah guru tetap dari ke 11 sekolah tersebut sebesar 383 guru.

Penentuan sampel menggunakan teknik Proportionate Random Sampling, teknik ini digunakan karna populasinya tidak homogen. Jumlah anggota sampel bertingkat (bertingkat) dilakukan dengan cara pengambilan sampel secara Proportional Random Sampling yaitu menggunakan rumus alokasi Proportional

Instrumen penelitian yang dipakai sebagai alat ukur kinerja guru adalah angket berisikan sejumlah butir-butir soal bersifat non tes. Analisis dilakukan secara kuantitatif. Pengakuan variabel kinerja guru, disusun dalam bentuk skala likert dengan empat pilihan alteratif jawaban: Skor pertanyaan: skor 4 = Sangat setuju, skor $3=$ Setuju, skor 2 = Ragu-ragu, skor $1=$ Tidak setuju.
Instrumen yang digunakan untuk mengukur supervisi akademik terhadap kinerja guru i menggunakan angket dengan skala Likert. Teknik analisis data menggunakan uji normalitas, uji linearitas, dan uji hipotesis. Uji Hipotesis menggunakan Uji hipotesis korelasi ganda (multiple correlation) yang digunakan untuk menguji hipotesis kuatnya hubungan antar dua variabel bebas secara bersama-sama dengan satu variabel terikat

\section{HASIL DAN PEMBAHASAN}

Pengujian prasarat analisis dilakukan dengan uji prasarat yang meliputi uji normalitas, setelah melaksanakan uji prasyarat selanjutnya dilakukan uji hipotesis.

\section{Uji Normalitas}

Hasil uji normalitas data supervisi akademik dilakukan dengan bantuan SPSS 20.0 for windows dengan melihat nilai kolmonogrof-smirnov. Hal uji normalitas dapat dilihat pada Tabel 1.

Tabel 1 Hasil Uji Normalitas Data

\begin{tabular}{|c|c|c|}
\hline Variabel & Asymp. Sig (1 tailed) & Keterangan \\
\hline $\begin{array}{c}\text { Supervisi } \\
\text { Akademik }\end{array}$ & 0,516 & Normal \\
\hline
\end{tabular}

Tabel 1 menunjukkan bahwa hasil dari kolmonogrof-smirnov variabel supervisi akademik dengan nilai 0,516>0,05, maka data dikatakan terdistribusi normal.

\section{Uji Hipotesis.}

Uji hipotesis pada penelitian ini ialah untuk mengetahui pengaruh supervisi akademik kepala sekolah terhadap kinerja guru dengan menggunakan

Hasil analisis regresi linier sederhana menggunakan SPSS disajikan pada Tabel 2.

Tabel 2. Hasil Analisis Pengaruh Supervisi Akademik Terhadap Kinerja Guru

\begin{tabular}{|c|c|c|c|c|}
\hline \multirow[b]{2}{*}{ Model } & \multicolumn{2}{|c|}{ Koefisien } & \multirow[b]{2}{*}{$t_{\text {hitung }}$} & \multirow[b]{2}{*}{ Sig. } \\
\hline & $\mathrm{B}$ & $\begin{array}{c}\text { Standar } \\
\text { Kesalahan }\end{array}$ & & \\
\hline Konstan & 29,222 & 7,658 & 3,816 & 0,000 \\
\hline $\begin{array}{l}\text { Supervisi } \\
\text { akademik }\end{array}$ & 0,647 & 0,102 & 6,319 & 0,000 \\
\hline
\end{tabular}

Tabel 2, termuat nilai thitung sebesar 6,319 lebih besar dari nilai ttabel sebesar 4,10 yang diperoleh dari jumlah responden 
dikurangi jumlah variabel, berarti 38 dengan taraf siginifikansi 0,05. Disimpulkan bahwa ada pengaruh supervisi akademik terhadap kinerja guru

Selanjutnya, hasil analisis diperoleh koefisien regresi kualitas layanan akademik sebesar 0,647, konstanta (intercept) sebesar 29,222, dan bentuk persamaan regresi $X$ terhadap $\mathrm{Y}$ adalah $\hat{\mathrm{Y}}=29,222+0,647 \mathrm{X}$, berarti perubahan satu unit variabel supervisi akademik diikuti oleh variabel kinerja guru sebesar 0,647 unit pada arah yang sama dengan intercept sebesar 29,222. Grafik persamaan regresi disajikan pada Gambar 1.

\section{Grafik Secara Parsial Supervisi Akademik (X)}

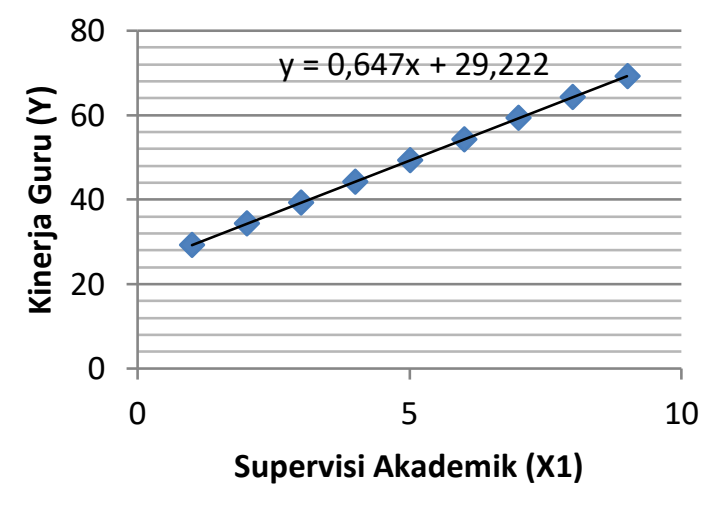

Gambar 1. Grafik Pengaruh Supervisi Akademik terhadap Kinerja Guru

Besarnya pengaruh supervisi akademik terhadap kinerja guru dapat dilihat dari koefisien R2 Terkoreksi disajikan pada Tabel 3.

Tabel 3. Hasil Analisis Besarnya Pengaruh Supervisi akademik terhadap Kinerja Guru

\begin{tabular}{|l|r|r|r|c|}
\hline \multirow{2}{*}{ Uraian } & \multicolumn{2}{|c|}{ Nilai } & \multirow{2}{*}{ F } & Sig. \\
\cline { 2 - 3 } & $\mathrm{R} 2$ & $\begin{array}{c}\mathrm{R} 2 \\
\text { Terkoreksi }\end{array}$ & \\
\hline $\begin{array}{l}\text { Supervisi } \\
\text { Akademik } \\
\text { terhadap } \\
\text { Kinerja Guru }\end{array}$ & 0,716 & 0,500 & 39,934 & 0,000 \\
\hline
\end{tabular}

Koefisien R2 Terkoreksi sebesar 0,500, artinya supervisi akademik memiliki pengaruh sebesar 50,0 \% terhadap kinerja guru.

Teknik yang digunakan kepala sekolah adalah teknik individu, teknik kelompok dan supervisi klinis. Faktor penghambat dalam pelaksanaan supervisi seperti kurangnya kompetensi beberapa supervisor, aktivitas di luar jadwal supervisi yang tidak direncanakan, sulit mengubah kebiasaan lama. Hasil penelitian ini membuktikan bahwa guru sebagai individu yang tidak sempurna dan makhluk sosial yang membutuhkan pertolongan, dekat dengannya untuk membantu dalam melaksanakan tugas dan tanggung jawabnya, dalam hal ini kompetensi guru dipengaruhi oleh pengaruh supervisi kepala sekolah. Hasil penelitian ini sejalan dengan penelitian Muhammad (2016) yang menyimpulkan bahwa terdapat hubungan yang positif antara persepsi guru terhadap supervisi kepala sekolah dengan guru efektif, tingkat kekuatan hubungan 0,85 dan sumbangan efektif $72,64 \%$. Selanjutnya Saani (2013) menyimpulkan bahwa terdapat pengaruh yang signifikan supervisi kepala sekolah terhadap kompetensi guru sekolah dasar di Kecamatan Sumowono, Semarang dengan koefisien determinasi 55,80\% .

Untuk meningkatkan kinerja guru, supervisi akademik harus dilaksanakan secara optimal. Rekomendasi berdasarkan hasil penelitian antara lain mengenai pelaksanaan supervisi akademik, kepala sekolah harus lebih memperhatikan pelaksanaan supervisi, sedangkan guru sebaiknya lebih meningkatkan kinerjanya terutama pada aspek evaluasi pembelajaran dan tindak lanjut hasil penilaian siswa. Hasil penelitian ini sesuai dengan hipotesis yang diajukan, dimana terdapat pengaruh supervisi kepala sekolah terhadap efektifitas guru Supervisi merupakan upaya pelayanan dan bantuan berupa bimbingan dari atasan (kepala sekolah) kepada pegawai sekolah (guru) dan petugas sekolah lainnya. Supervisor bertindak sebagai stimulator, konselor dan konsultan bagi guru dalam meningkatkan pengajaran dan menciptakan situasi belajar mengajar yang baik. Selain itu, supervisi diharapkan membawa dampak pembangunan yang baik 
bagi kemajuan proses pengajaran melalui penyempurnaan kurikulum yang ada di sekolah sebagai salah satu sarana dalam meningkatkan mutu pendidikan (Renata, et al., 2018).

Peran Kepala Sekolah sangat dominan dan merupakan posisi sentral di sekolahnya terutama menyangkut kebijakan dalam pengambilan keputusan. Supervisi akademik dapat meningkatkan kinerja guru dengan meningkatkan kualitas pembelajaran (Kartini, et al., 2020). Adanya supervisi akademik yang dilakukan oleh kepala sekolah akan memotivasi guru untuk meningkatkan kinerjanya karena guru merasa terbantu dan diperhatikan oleh pimpinan.

Indikator yang terdapat pada kompetensi profesional yang dikemukakan dalam penelitian memberikan pemahaman bahwa guru harus menguasai materi, struktur, dan konsep mata pelajaran yang dimilikinya, menguasai kompetensi inti dan kompetensi dasar serta mengembangkan materi secara kreatif. Selain itu, untuk menciptakan kinerja yang baik guru harus mengembangkan diri dalam kegiatan pengembangan keprofesian yang berkelanjutan, serta harus mampu memanfaatkan teknologi dan informasi. Kinerja guru yang meliputi kegiatan perencanaan pembelajaran, pelaksanaan pembelajaran, hubungan interpersonal, evaluasi hasil belajar, remedial, dan pengayaan tentunya merupakan syarat mutlak untuk menghasilkan pembelajaran yang berkualitas.

Hasil penelitian ini didukung oleh penelitian sebelumnya yang dilakukan oleh Hardono et al. (2017) bahwa kepemimpinan kepala sekolah yang baik akan meningkatkan kinerja guru. Kemudian Rachmawati (2013) melalui hasil penelitiannya menunjukkan bahwa terdapat pengaruh kepemimpinan kepala sekolah terhadap kinerja guru sebesar $15,1 \%$ sedangkan sisanya dipengaruhi oleh faktor lain.

Rachmawati menyimpulkan bahwa kinerja guru di sekolah sangat bergantung pada bagaimana kemampuan kepala sekolah mempengaruhi perilaku guru dalam menjalankan tugasnya. Demikian pula penelitian dari Setiyati (2014) menunjukkan bahwa jika seorang guru didukung oleh kepemimpinan kepala sekolah yang baik maka guru tersebut cenderung memiliki kinerja yang baik dan profesional. Artinya semakin tinggi kepemimpinan kepala sekolah maka semakin baik pula kinerja gurunya.

Hasil penelitian Suhayadi (2018) menunjukkan bahwa kinerja guru akan lebih profesional jika diimbangi dengan pelayanan supervisi akademik yang rutin dan terstruktur kepada kepala sekolah sebagai budaya sekolah yang berkualitas. Selain itu, penelitian Hardono et al (2017) dan, Irfan (2018) menunjukkan bahwa supervisi akademik yang baik akan meningkatkan kinerja guru. Penelitian yang dilakukan Hasanah dan Kristiawan (2019) juga menyimpulkan bahwa semakin baik pelaksanaan supervisi akademik maka kinerja guru akan semakin meningkat. Dalam penelitiannya nilai dimensi supervisi akademik yang kecil adalah menetapkan tujuan, karena diperlukan perencanaan yang matang dalam pelaksanaan supervisi akademik.

Penelitian ini juga didukung oleh penelitian dari Sopandi (2019) hasil penelitian menunjukkan bahwa kompetensi profesional mempunyai pengaruh yang signifikan terhadap kinerja guru. Menurutnya, kemampuan menguasai materi ajar bersifat mutlak, tidak bisa ditawar. Penelitian Patarai et al (2018) dan Yustiyawan dan Nurhikmahyanti (2014) juga mendukung hasil penelitian ini bahwa kompetensi profesional berpengaruh positif dan signifikan terhadap kinerja guru.

Terdapat pengaruh langsung antara kompetensi profesional dengan kinerja guru, kompetensi profesional merupakan syarat sebelum guru melaksanakan tugasnya dalam proses pembelajaran Selanjutnya penelitian Hardono et al (2017) membuktikan peningkatan kinerja guru melalui kepemimpinan kepala sekolah. Supervisi akademik melalui motivasi kerja dengan hasil penelitian menunjukkan nilai F-test $(51,172)$ dengan tingkat signifikan $(0,000)<0,05$. Penelitian ini semakin membuktikan 
peningkatan kinerja guru melalui kepemimpinan kepala sekolah dan supervisi akademik. Demikian pula penelitian Wardani (2019) menunjukkan bahwa kinerja guru dipengaruhi oleh supervisi kepala sekolah dan kompetensi profesional sebesar 10,80\% dan sisanya dipengaruhi oleh faktor lain. Perencanaan supervisi yang baik yang disesuaikan dengan kebutuhan guru akan menyukseskan program supervisi, serta meningkatkan kompetensi profesional yang dibutuhkan supervisi kepala sekolah.

Menurut hasil penelitian Ridwan dan Sopandi (2018) kepemimpinan kepala sekolah, kompetensi guru, dan kompensasi berpengaruh terhadap kinerja guru sebesar 67,3\%. Artinya jika kepala sekolah menjalankan fungsinya secara profesional, kompetensi guru juga terjaga dengan baik, dan diberikan kompensasi yang sesuai maka akan berdampak signifikan terhadap kinerja guru.

\section{KESIMPULAN}

Berdasarkan analisis data dan pengujian hipotesis dalam penelitian ini, dapat diambil kesimpulan sebagai berikut. Ada pengaruh antara kepemimpinan kepala sekolah terhadap kinerja guru SMAN di Kota Mataram, artinya kepemimpinan kepala sekolah yang baik akan meningkatkan kinerja guru. Terdapat pengaruh antara supervisi akademik terhadap kinerja guru SMA di Kota Mataram, penerapan supervisi akademik yang baik akan meningkatkan kinerja guru, penerapan supervisi akademik yang baik akan meningkatkan kinerja guru.

\section{DAFTAR PUSTAKA}

Andriani, S., Kesumawati, N., \& Kristiawan, M. (2018). The Influence of the Transformational Leadership and Work Motivation on Teachers Performance. International Journal of Scientific \& Technology Research, 7(7), 19-29.

Arikunto, S. (2013). Prosedur Penelitian Suatu Pendekatan Praktik. Jakarta: PT Rineka Cipta.
Fathurrahman, F. (2018, October). Asistensi Supervisi Pengajaran Kepala Sekolah Untuk Meningkatkan Profesionalisme Guru. In Proceedings of Annual Conference on Community Engagement (pp. 1144-1155).

Ghaffar, S., Hamid, S., \& Thomas, M. (2019). Impact of Teacher's Self-Efficacy on Student's Motivation towards Science Learning. Review of Economics and Development Studies, 5(2), 225-234.

Hardono, H., Haryono, H., \& Yusuf, A. (2017). Kepemimpinan Kepala Sekolah, Supervisi Akademik, dan Motivasi Kerja dalam Meningkatkan Kinerja Guru. Educational Management, 6(1), 26-33.

Hasanah, M. L., \& Kristiawan, M. (2019). Supervisi Akademik dan Bagaimana Kinerja Guru. Jurnal Studi Manajemen Pendidikan, 3(2), 97112.

Irfan, A. (2018). Supervisi Akademik Kepala Sekolah Dan Kompensasi Dalam Kinerja Mengajar Guru. Jurnal Administrasi Pendidikan, 25(2), 264274.

Kartini, D., Kristiawan, M., \& Fitria, H. (2020). The Influence of Principal's Leadership, Academic Supervision, and Professional Competence toward Teachers' Performance. International Journal of Progressive Sciences and Technologies, 20(1), 156-164.

Khasanah, U., \& Kristiawan, M. T. (2019). The Implementation of Principals' Academic Supervision In Improving Teachers' Professionalism in the State Primary Schools. International Journal of Scientific \& Technology Research, 8(8).

Muhammad, I. (2016). The Impact of Supervision, Motivation and Work Ethic on Teachers' Professional Competence: A Case Study of Private Islamic High School Teachers. The Impact of Supervision, Motivation and Work 
Ethic on Teachers' Professional Competence: A Case Study of Private Islamic High School Teachers, 6(1).

Mujahidin, M. (2017). Pengaruh Supervisi Akademik Pengawas Sekolah Terhadap Kinerja Guru Mata Pelajaran IPA di SMPN Tungkal Jaya. Biota, 10(1), 35-54.

Murtiningsih, M., Kristiawan, M., \& Lian, B. (2019). The Correlation Between Supervision of Headmaster and Interpersonal Communication With Work Ethos of the Teacher. European Journal of Education Studies

Patarai, I., Mustari, M., \& Azis, M. (2018). Motivasi Mengajar, Kompetensi Profesional dan Tingkat Pendidikan terhadap Kinerja Guru. Jurnal Mirai Management, 3(2), 120-133.

Rachmawati, Y. (2013). Pengaruh kepemimpinan kepala sekolah terhadap kinerja guru. Jurnal Ekonomi, 1(1).

Ramdani, A. (2020, May). Developing Inquiry-Based Learning Materials Through Integrated Lesson Study with 4-D Model to Enhance Junior High School Students' Critical Thinking Skill. In 4th Asian Education Symposium (AES 2019) (pp. 236-238). Atlantis Press.

Renata, R., Wardiah, D., \& Kristiawan, M. (2018). The Influence of Headmaster's Supervision and Achievement Motivation on Effective Teachers. International Journal of Scientific \& Technology Research, 7(4), 44-49.

Resawati, R., \& Larashati, I. (2017). Pengaruh Kepemimpinan Kepala Sekolah, Kompetensi Guru Dan Kompensasi Terhadap Kinerja Guru. Jurnal Ekonomi, Bisnis \& Entrepreneurship, 10(2), 132-148.

Saani, A. J. (2013). Influence of compensation and supervision on private basic school teachers work performance in Ashaiman
Municipality. International journal of business and social science, 4(17).

Setiyati, S. (2014). Pengaruh kepemimpinan kepala sekolah, motivasi Kerja, dan budaya sekolah terhadap kinerja guru. Jurnal Pendidikan Teknologi dan Kejuruan, 22(2), 200-206.

Sopandi, A. (2019). Pengaruh Kompetensi Profesional dan Kompetensi Kepribadian Terhadap Kinerja Guru. Scientific Journal of Reflection: Economic, Accounting, Management and Business, 2(2), 121-130.

Suchyadi, Y. (2018). Relationship between Principal Supervision in Increasing the Job Satisfaction of Private Junior High School Teachers in East Bogor District. JHSS (Journal Of Humanities And Social Studies), 2(1), 26-29.

Wardhani, E. S. (2019). Persepsi Guru Tentang Kompetensi Supervisi Kepala Sekolah dan Profesional Guru Dengan Kinerja Guru di SMA 1926 Pamulang. Jurnal Madani: Ilmu Pengetahuan, Teknologi, dan Humaniora, 2(2), 289-303.

Yustiqvar, M., Gunawan, G., \& Hadisaputra, S. (2019, December). Green Chemistry Based Interactive Multimedia on Acid-Base Concept. In Journal of Physics: Conference Series (Vol. 1364, No. 1, p. 012006). IOP Publishing.

Yustiyawan, R. H., \& Nurhikmahyanti, D. (2014). Pengaruh Motivasi dan Kompetensi Profesional Guru. Jurnal Inspirasi Manajemen Pendidikan, 3(3), 114-123. 